\title{
Exploration of Bacillus thuringiensis ä-Endotoxin Derived from Bacterial Isolates in Jabodetabek Region
}

\author{
EDDY JUSUF \\ Division of Molecular Biology, Research Center for Biotechnology, Lembaga Ilmu Pengetahuan Indonesia, \\ Jalan Raya Jakarta-Bogor Km.46 Cibinong, Bogor 16911, Indonesia \\ Phone: +62-21-8754587, Fax:+62-21-8754588,Email:eddy-jusuf@indo.net.id
}

\begin{abstract}
Bacillus thuringiensis is a well-known species of bacteria producing parasporal crystalline proteins that are toxic to many insect pests, it also has strong cytocidal activity against human cancer cells. In this work we endeavoured to explore the city of Jakarta and its neighbouring regencies to obtain new strains to profile its potency. The soil samples were boiled and plated on T-3 agar; the colonies which appeared were then examined under the light microscope to check for crystalline proteins. The proteins were treated with $1 \%$ SDS- $0.01 \% \beta$-mercaptoethanol and visualized by SDS-PAGE to determine their molecular size. From 52 soil samples, 1248 putative colonies were obtained. After microscopic examination, 57 isolates showed the existence of crystalliferous protein, of those 30 indicated many sizes of ä-endotoxin protein from approximatively $150 \mathrm{kDa}$ to the smallest $35 \mathrm{kDa}$. Most of proteins examined probably showed insecticidal activity and four of those were predicted to possess cytocidal activity against human cancer cells. The geographic condition did not appear to influence the distribution of different types of äendotoxin.
\end{abstract}

Key words: Bacillus thuringiensis, local strains, ä-endotoxin

Bacillus thuringiensis is a Gram positive spore forming bacterium, constituting a large family of strains found in different and high specialized habitats (Bernhard et al. 1997; Chaufaux et al. 1997). This bacterium produces parasporal crystalline protein inclusions (ä-endotoxins), also called Cry proteins, that have a natural insecticidal effect on insect pests of the Lepidoptera, Coleoptera, Diptera, Hymenoptera, Homoptera, Orthoptera and Mallophaga orders, and against mites, platyhelminthes and nematodes. They also have germicidal activity on protozoa of medical importance such as Plasmodium berghei (Schnepf et al. 1998). Nowadays, more than 133 types of crystal protein comprising 24 primary ranks are systematically found. Molecular sizes of these proteins vary from $25 \mathrm{kDa}$, found in $B$. thuringiensis subsp. israelensis, to $135 \mathrm{kDa}$ polypeptides in many others.

Interestingly, recent investigators have provided evidence that parasporal inclusion proteins of certain noninsecticidal $B$. thuringiensis isolates occasionally exhibit in vitro cytocidal activities on human cancer cells. Proteins with this unique function are now categorized into a group designated parasporin (Mizuki et al. 1999; Xu et al. 2004). An isolate of B. thuringiensis serovar shandongiensis exhibits strong cytocidal activity against human leukaemic $\mathrm{T}$ cells (Lee et al. 2000). Lee et al. (2001) also reported that a 28 $\mathrm{kDa}$ protein produced from this strain was a cytotoxic substance against human leukaemic T cells, and suggested that another protein cytotoxic against HeLa cells might also exist. Until now, there are four groups of parasporin protein, PS-1 known as Cry31 protein having a molecular weight of 81 kDa , PS-2 known as Cry 46 (37 kDa), PS-3 known as Cry $41(88 \mathrm{kDa})$ and PS-4, known as Cry 45 having $34 \mathrm{kDa}$ protein (Ohba et al. 2009).

Until March 2002, over 359 different genes of Cry protein have been identified, more than 97 different genes of Cry protein have been cloned from $B$. thuringiensis to many other bacteria and plant species, and more than 16 thousand of strains are kept in collection all over the world (Crickmore $e t$ al. 2002). Among the strains listed, no one has been obtained from any region of Indonesia, nor carrying a taxon name of typical of an Indonesian region such as B. thuringiensis subsp. malaysiensis which was obtained from Malaysia. In reality, Indonesia is known as the second country having the highest diversity of biological resources after Brazil. The aim of this study was to find native strains of $B$. thuringiensis from local natural resources. The first exploration began in Jabodetabek (abbreviation of Jakarta, Bogor, Tanggerang, Depok and Bekasi), a large area covering Jakarta, the capital of the country, with their municipalities and regencies, and this area covers about $4563 \mathrm{~km}^{2}$. This study was limited to finding the types of ä-endotoxins distributed in this region and to predict the potencies of those proteins based on their molecular weight, in agriculture or medical fields for the next works.

\section{MATERIALS AND METHODS}

Sampling. The sampling was conducted in Jakarta municipalities, Depok, Bekasi and its regency, Tangerang, Bogor and its regency. Samples were randomly collected from environmentally diverse sources (including beach sand, forest soil, aquatic and intertidal sediments, and soils from urban, rural and agricultural areas), placed in a plastic bag and held at room temperature until processing. From Central Jakarta we have 7 soil samples (no 16 to 22), one sample (no 23) from southern Jakarta and two samples (no 41 and 42) from Eastern Jakarta. From the Municipality of Depok (Sukmajaya district), only two soil samples (no 43 and 44) were collected; from Bekasi regency 8 soil samples of Muara Tawar coast area (no 8 to 15) and 6 samples (no 35 to 40) of Bojong village were obtained. From Bogor, 7 samples were obtained from Cibinong district (no 1 to 7), 6 samples from Bogor town (no 24 to 29) and 5 samples (no 30 to 34) were obtained from mountainous outskirts of Bogor. Only one sample was obtained from Tanah Tinggi district of Tangerang town centre area (no 45). As a supplement, six samples (no 46 to 51) from the Sukabumi regency (adjoining the southern Bogor regency), out of Jabodetabek area were added. 
Bacterial Isolation. For specifically isolating $B$. thuringiensis strains, the method was as described by Travera et al. (1987), where $1.0 \mathrm{~g}$ samples were introduced into a test-tube containing $10 \mathrm{~mL}$ phosphate buffer $0.05 \mathrm{M}$ at pH 6.8 and shaken vigorously for $15 \mathrm{~min}$. The tubes were then heated at $70{ }^{\circ} \mathrm{C}$ for $30 \mathrm{~min}$ in a water-bath and shaken vigorously for a second time to disperse the spores. Aliquots of 5, 10, 25 and $50 \mu \mathrm{L}$ of suspension were poured on Petri plates containing T-3 agar (for 1.0 L of final solution, containing $3 \mathrm{~g}$ tryptone, 2 g tryptose, $1.5 \mathrm{~g}$ yeast extract, $0.05 \mathrm{M} \mathrm{Na}_{3} \mathrm{PO}_{4}, 0.005 \mathrm{M} \mathrm{MnCl}_{2}$ in $12 \mathrm{~g}$ agar). The cultures were incubated at $28^{\circ} \mathrm{C}$ for about $48 \mathrm{~h}$ until colonies appeared. The number of total colonies, and the colonies which resembled exactly to standard strains Bts 002199A were counted. From each sample, 24 B. thuringiensis-like colonies were transferred to the fresh T-3 agar medium on the Petri glass and reincubated at $28{ }^{\circ} \mathrm{C}$ for sporulation over $72 \mathrm{~h}$. Microscopic observation using a phase contrast microscope Zeiss 003-002199 Axiophate was performed to verify the presence of crystal proteins (Cry protein). The crystalliferous colonies observed were harvested as the new isolates and conserved in Luria-Bertani slant agar for ä-endotoxin profiling.

Profiling of ä-Endotoxins. The crystalliferous isolates being tested for the ä-endotoxin profiling were previously grown on Luria-Bertani agar Petri for 2 x overnight before being inoculated onto T-3 agar for sporulation. The method used for this protein-profiling was as described by Bel et al. (1997), where sporulated colonies growing (48 to $72 \mathrm{~h}$ ) in T-3 agar plate were harvested and poured into chilled $1 \mathrm{~mL}$ $500 \mathrm{mM} \mathrm{NaCl}$ in $1.5 \mathrm{~mL}$ microtube. The suspensions were centrifuged $13800 \mathrm{x}$ g for $10 \mathrm{~min}$, and the sediment obtained was again suspended in $150 \mu \mathrm{L} 1 \%$ SDS-0.01\% $\beta$-mercaptoethanol and heated at $110{ }^{\circ} \mathrm{C}$ for $10 \mathrm{~min}$ to solubilize the crystals. The suspensions were again centrifuged at $13800 \mathrm{xg}$ for $10 \mathrm{~min}$. The supernatant obtained was mixed with an equal volume of sample buffer $(0.15 \mathrm{M}$ Tris.Cl pH 8.8, 3.75 mM EDTA, 0.75 M sucrose, $0.075 \% \mathrm{w} / \mathrm{v}$ bromophenolblue, $2.5 \% \mathrm{w} / \mathrm{v}$ SDS and $7.4 \mathrm{mM}$ dithiothreitol). The mixture was heated $100{ }^{\circ} \mathrm{C}$ before visualized using electrophoresis.

SDS-PAGE. To obtain the profile of ä-endotoxin from each isolate, vertical electrophoresis using polyacrylamide mixed with sodium dodecyl sulfate (Laemmli 1970) was performed. Electrophoretic Protean II equipment (Amersham) was used with a separating gel of $10 \%(w / v)$ acrylamide. Electrophoresis was performed at 75 volt using Tris-Glycine buffer (50 mM Tris, $384 \mathrm{mM}$ glycine and $0.1 \%$ (w/v) sodium dodecyl sulfate). To determine molecular weights, a Combithek (Boehringer Mannheim cat. No. 1317-474) standard kit having the range 14.307 to $340 \mathrm{kD}$ was used. Gels were stained with $0.1 \%$ (w/v) Comassie blue, $50 \%$ (v/v) methanol and 10\% (v/v) acetic acid; and then destained by boiling the gels in water.

\section{RESULTS}

Microscopic Observation. From 51 soil samples, a total 1248 colonies were selected for microscopic observation. Some samples were devoid of bacteria containing crystals, e.g. in the soil sample of Southern Jakarta (no 23) and of
Eastern Jakarta (no 41), from Bogor region (no 1, 2, 23, 24, 25 , 26, 28, 30, 34), from Depok (no 43 and 44), from Tangerang (no 45), from Bekasi (no 13, 14 and no 39). From Sukabumi only one sample (no 50) yielded two of crystalliferous isolates, for the others (no 46, 47, 48, 49 and 51) no crystalliferous isolate was obtained. In total, from hundred colonies appeared which resembled exactly to standard strains Bts 002199A in the plate of each sample, only 24 to 32 colonies selected to be observed under microsscope for the presence of crystal. The total number of crystalliferous isolates obtained after microscopic observation was 57, consisting of 20 isolates from Central Jakarta and 3 from Eastern Jakarta, 20 isolates from the whole Bogor region were divided into 9 from the Cibinong district, 3 from Bogor town and 8 from Bogor the upland plains. The 15 isolates from Bekasi comprise of 8 isolates from the Muara Tawar coast area and 7 isolates from Bojong village. There were 2 isolates from Sukabumi. The number of isolates showing the presence the ä-endotoxin-protein-crystal obtained in each sample varied from one to five. The proteins obtained from the culture of those isolates were examined by SDS-PAGE for identifying the type of Cry protein present.

Protein Profiling. Protein profiles obtained from Cibinong (Bogor) isolates are shown in Fig 1a. From 9 isolates previously predicted as $B$. thuringiensis, there were two isolates which produced ä-endotoxin (isolate $3 \mathrm{~L}$ from soil of housing grassland with protein weight molecular of about $130 \mathrm{kDa}$, as well as isolate $6 \mathrm{c}$ obtained from the mud). The ä-endotoxin is thought to be Cry1 or Cry4. From soil under rambutan (Nephelium lapaceum) trees the isolate $5 \mathrm{~K}$ was detected having three crystal proteins of about 100 $\mathrm{kDa}, 85 \mathrm{kDa}$, and $35 \mathrm{kDa}$ each thought to be protein Cry25Aa1, Cry2 or Cry 3 and Cry30Aa1. The isolate $3 \mathrm{~A}, 3 \mathrm{~N}$, 4Q (from soil under guava tree), 6L, 7E and 7I (from an insect cadaver near our laboratory) would be similar strains, which were previously identified as $B$. cereus, from which no ä-endotoxin was present. The second gel (Fig 1b) shows the protein profile of all isolates obtained from Muara Tawar coast area of the Bekasi region. Isolate $8 \mathrm{c}$ from the soil taken under the waru tree (Hibiscus tiliaceus) had one Cry protein band of $130 \mathrm{kDa}$, representating Cry1. Very dense spots of äendotoxin is found for isolate $9 \mathrm{G}$ obtained from the soil of post harvest rice field and found to contain 2 ä-endotoxins of about $135 \mathrm{kDa}$ and $120 \mathrm{kDa}$. Isolate $8 \mathrm{~N}, 11 \mathrm{~L}$ (from soil under mangroves in a fishering village), $12 \mathrm{G}$ (from mud of a milkfish (Chanos chanos) pond, 15I and 15L (from soil of uncultivated land at a Vapour and Gas Electricity Generator Centre) are similar, being devoid of ä-endotoxin.

The ä-endotoxins present in the bacterial isolates obtained from Central Jakarta are shown in Fig 1c and 1d. Some isolates contained Cry protein, among them isolate 16G $(120 \mathrm{kDa}$ ) and 16J (having two bands of 120 and $135 \mathrm{kDa}$ ). Both were obtained from garden soil under the National Monument. Isolates 19A and 19S (obtained from soil around the Liberation Monument of Lapangan Banteng) seems to be similar containing 3 bands of $130 \mathrm{kDa}, 85 \mathrm{kDa}$ and $45 \mathrm{kDa}$, 20Q (from soil around the Istiqlal mosque) containing $85 \mathrm{kDa}$; $21 \mathrm{~F}$ (soil from the roadside of Liberation Monument of Lapangan Banteng) which shows a thick band at about 150 $\mathrm{kDa}$. Lanes 21G, 21I, 21L and 22P seems to be similar in profile, and are considered as the same strains as B. cereus. 
From Bogor town center and its mountainous landscape surrounding (Fig 1e and 1f), two strains, each 31A and 31T (both obtained from the soil of the camping ground of Cilember), $32 \mathrm{~N}$ (soil from the Natural Forest Reserve of Cilember) show the same profile as $21 \mathrm{f}$, having a thick band of about $150 \mathrm{kDa}$. Isolates $27 \mathrm{~B}$ (from soil taken from the yard of Faculty of Technique, Universitas Pakuan, Bogor), 29G and $29 \mathrm{H}$ (soil taken from Bogor Botanical Garden), 31E (from the soil of camping ground of Cilember), 32B (soil from Natural Forest Reserve of Cilember), 33B and 33T (both the soil from Pinus spp. Plantation in Salak mountain) and the two standard
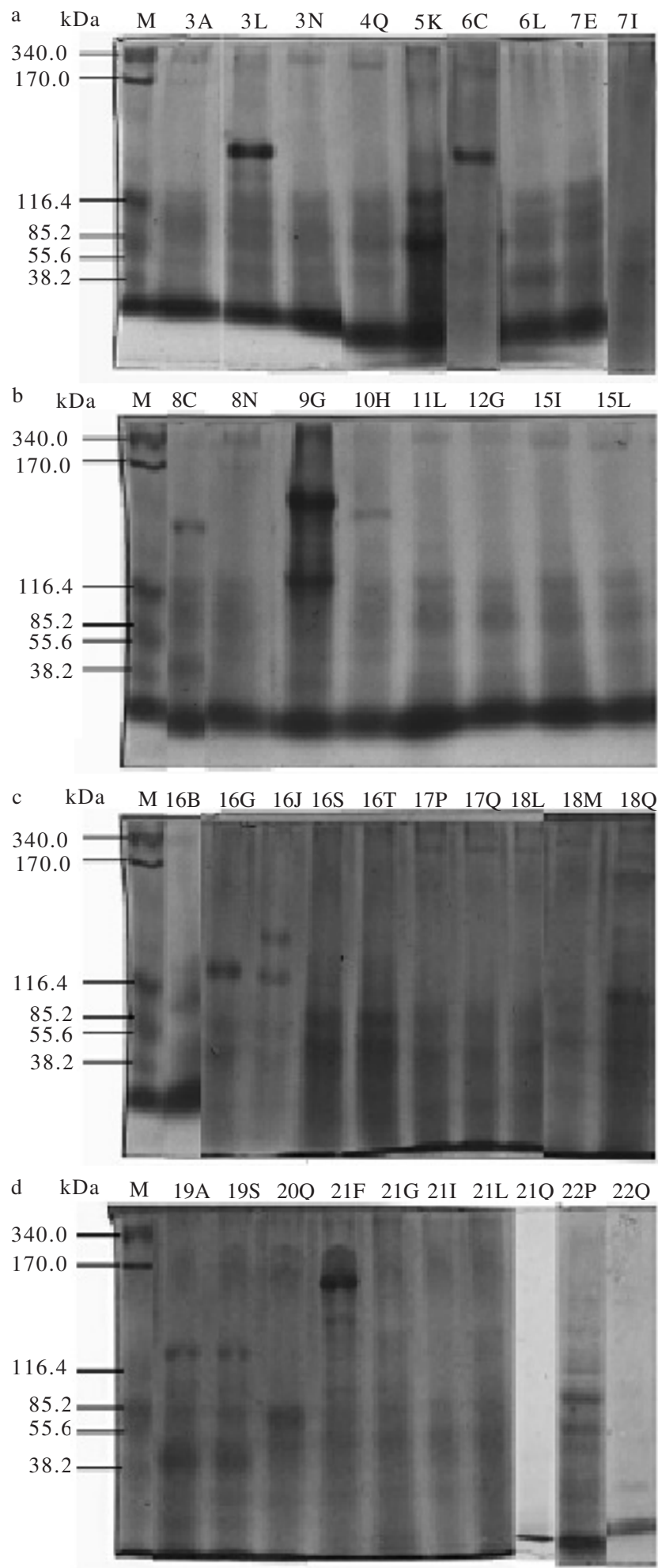

strains B. thuringiensis var. Berliner HD-2, subsp. galleriae HD-29 show the same profile, having Cry protein of about 70 $\mathrm{kDa}$, akin to Cry $2 \mathrm{Aa}$ or Cry $2 \mathrm{Ab}$.

The protein profile of other isolates obtained from the farm village of Bojong (Bekasi) in Fig 1f and 1g, show the same profile as Cry protein $(135 \mathrm{kDa})$ which is the same as the standard strain of $B$. thuringiensis var. aizawai HD-137 as well as var. israelensis HD-567. The isolates showing this protein type are 35R (obtained in soil taken from a house yard of the village), 37T3 (from the soil under Morinda citrifolia tree attacked by insect larvae), 40A, 40G and 40I, all isolated from soil taken from a chicken barn. All isolates obtained from soil of unutilized land in a housing area of
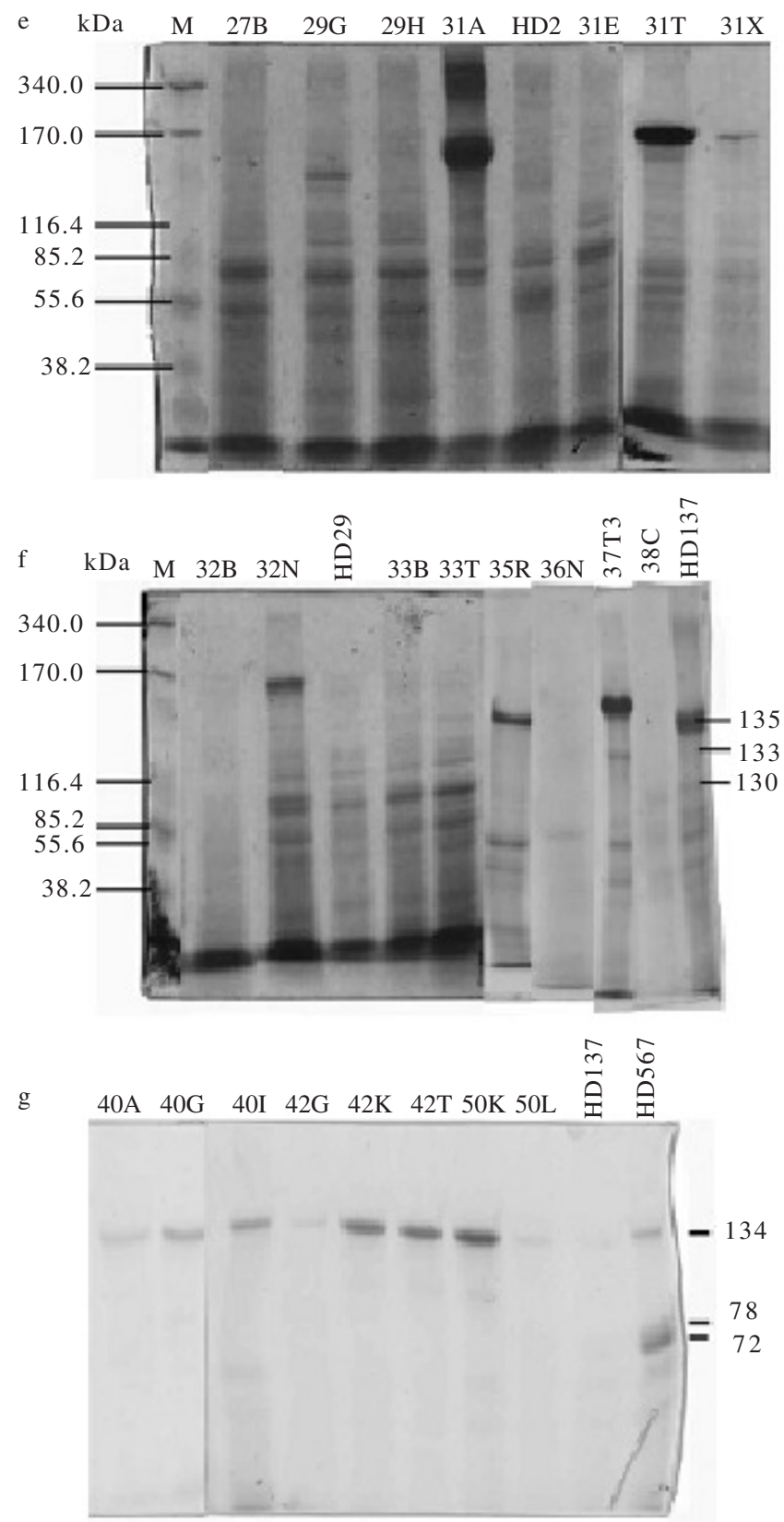

Fig 1 SDS-10\%PAGE of B. thuringiensis ä-endotoxin proteins representatives of the main profiles listed in Table1: a, isolates from Cibinong district; $\mathrm{b}$, isolates from Muara Tawar coast area; $\mathrm{c}$ and d, from Central Jakarta; e, from Central Bogor and its mountainous landscape (no.31a,31e,31t and 31x); f, from Bogor with surrounding mountains and Bojong village of Bekasi; $\mathrm{g}$, from Bojong village of Bekasi, Cipayung, Eastern Jakarta and Sukabumi. 
Cipayung (Eastern Jakarta), isolates 42G, 42K and 42T, and one of the two isolates from Situgunung-Sukabumi, (50K) show the same profile as the isolates from Bojong.The total yields of ä-endotoxins obtained from this work is presented in Table 1.

\section{DISCUSSION}

The first results in previous page reported that 17 samples were devoid of bacteria containing crystals observed under microscopic observation. It could not be said the absence of the bacteria producing parasporal crystalline proteins in the area where the samples were taken. From hundred colonies appeared which resembled exactly to standard strains in the plate of each sample, only 24 to 32 colonies selected to be observed under microsscope for the presence of crystal. It was possible that, by such random selection, the bacteria targeted were slipped away. From 57 isolates tested by protein-profiling, 40 of them showed the existence of ä-endotoxin. The uncommonly large protein crystal size $( \pm 150 \mathrm{kDa})$ was found in four isolates from Central Jakarta and Central Bogor, 21F, 31A, 31T and 32N. This type protein was previously declared by Schnepf et al. (1992) as CryV protein having specifically toxicity to some species of Nematodes present in the strain PS17a of B. thuringiensis. This type of protein is not broadly studied because it is known that the ä-endotoxin is generally toxic to insects. It is interesting that those strains were obtained in lowland plains and upland plains. Although the protein profile is similar, a serology test is necessary to distinguish those subspecies and other molecular tests to establish the precise strain.

The most common large protein crystal size is the $135 \mathrm{kDa}$, belonging to Cry $4 \mathrm{Ba} 1$ protein having specific toxicity to some species of mosquito. This protein type was found distributed almost in all areas studied in this work, where we get 11 isolates from the coastal area of Bekasi, lowland plains of Jakarta and Bekasi up to upland mountainous areas of Bogor and Sukabumi. On the other hand, the distribution is correlated with the existence of this insect as the host for bacterial proliferation. The isolate $9 \mathrm{C}$ and $16 \mathrm{~J}$ producing this protein, they produce also the $120 \mathrm{kDa}$ protein that is probably Cry4Aa being effective to kill mosquito larvae.

Protein of the molecular size from 130-133 kDa generally belong to Cry I, from Cry $1 \mathrm{Aa} 1$ to Cry $1 \mathrm{Ib} 1$ as denoted in the composed data of known Cry protein gathered having specific toxicity to Lepidoptera larvae. In this study we found that the isolates carrying this type of protein originated from the lowland plains area of Jakarta, Bogor and Bekasi, and not found in mountainous areas. Inversely the molecular size of protein 120-125 kDa belong to Cry 4Aa and Cry 4Ab groups which are toxic towards Diptera larvae, mainly mosquitoes. Only one isolate from Cibinong Bogor $(5 \mathrm{~K})$ showed a protein of $100 \mathrm{kDa}$ molecular size. Such a protein is postulated as being Cry 25Aa1, which was previously discovered in a strain B. thuringiensis var. medellin 163-13 isolated from Medellin, Colombia and which are toxic to mosquito larvae. This isolate $5 \mathrm{~K}$ has two other ä-endotoxins of 85 and $35 \mathrm{kDa}$, where the $85 \mathrm{kDa}$ protein are also carried by isolate 20Q. This is thought to be Cry2Ac having low toxicity against Lepidoptera and Diptera or possibly Cry 41 (PS-3) protein of $88 \mathrm{kDa}$ molecular weight having low cytocidal activity againts cancer cells (Ohba et al. 2009). Meanwhile the ä-endotoxin of $35 \mathrm{kDa}$ is thought to be Cry 30Aal having toxicity against mosquito or possibly to be Cry45 (PS-4) possesing $34 \mathrm{kDa}$ protein or Cry46 (PS-2) possesing $37 \mathrm{kDa}$ protein, the last two were reported having high cytocidal activity againts cancer cells. Isolates $19 \mathrm{~A}$ and $19 \mathrm{~S}$ seems to be similar containing 3 bands of $130 \mathrm{kDa}, 85 \mathrm{kDa}$ and $45 \mathrm{kDa}$, where $130 \mathrm{kDa}$ protein could be CryI, $85 \mathrm{kDa}$ protein could be Cry 2 Ac or PS-3, and $45 \mathrm{kDa}$ protein could be protein Mtx 3 being obtained in strain $B$. thuringiensis subsp. galleriae.

The results showed that geographic condition did not influence the different types of ä-endotoxins where all those proteins could be found somewhere. The molecular weight of the proteins found in those strains was still approximative and must be verified by other technique more sophisticated than SDS-PAGE used here. Anyhow, all those strains producing ä-endotoxins will be used in the next study as

Table 1 ä-endotoxins distribution among B. thuringiensis isolates obtained based on the SDS-PAGE yields,mass molecular category and its type Cry protein predicted

\begin{tabular}{|c|c|c|c|}
\hline Category & Type of ä-endotoxins predicted & $\begin{array}{l}\text { Isolate numbers carrying } \\
\text { those protein type }\end{array}$ & Origin of the isolates \\
\hline \multirow[t]{2}{*}{$>150 \mathrm{kDa}$} & Cry V & $21 \mathrm{~F}$ & Central Jakarta \\
\hline & & $31 \mathrm{~A}, 31 \mathrm{~T}$ and $32 \mathrm{~N}$ & Central Bogor \\
\hline \multirow[t]{5}{*}{$135 \mathrm{kDa}$} & Cry $4 \mathrm{Ba}$ & $9 \mathrm{C}$ & Bekasi coastal area \\
\hline & & $16 \mathrm{~J}$ & Central Jakarta \\
\hline & & $35 \mathrm{R}, 37 \mathrm{~T} 3,40 \mathrm{~A}, 40 \mathrm{G}, 40 \mathrm{I}$ & Bekasi, Bojong village \\
\hline & & $42 \mathrm{G}, 42 \mathrm{~K}$ and $42 \mathrm{~T}$ & Eastern Jakarta \\
\hline & & $50 \mathrm{~K}$ & Sukabumi area \\
\hline \multirow[t]{3}{*}{$130 \mathrm{kDa}$} & Cry I or Cry 4 & $3 \mathrm{~L}$ and $6 \mathrm{C}$ & Cibinong, Bogor \\
\hline & & $8 \mathrm{C}$ & Bekasi coastal area \\
\hline & & 19A, 19S & Central Jakarta \\
\hline \multirow[t]{2}{*}{$120 \mathrm{kDa}$} & Cry $4 \mathrm{Aa} 1$ & $9 \mathrm{C}$ & Bekasi coastal area \\
\hline & & $16 \mathrm{G}, 16 \mathrm{~J}$ & Central Jakarta \\
\hline $100 \mathrm{kDa}$ & Cry $25 \mathrm{Aa} 1$ & $5 \mathrm{~K}$ & Cibinong, Bogor \\
\hline \multirow[t]{2}{*}{$85 \mathrm{kDa}$} & Cry 2 or Cry 3 & $5 \mathrm{~K}$ & Cibinong, Bogor \\
\hline & & 19A, 19S and 20Q & Central Jakarta \\
\hline $70 \mathrm{kDa}$ & Cry $2 \mathrm{Aa}$ or Cry $2 \mathrm{Ab}$ & $27 \mathrm{~B}, 29 \mathrm{G}, 31 \mathrm{E}, 32 \mathrm{~B}$ and $33 \mathrm{~B}$ & $\begin{array}{l}\text { Central Bogor with } \\
\text { surrounding mountains }\end{array}$ \\
\hline $45 \mathrm{kDa}$ & Mtx 3 & $19 \mathrm{~A}$ and $19 \mathrm{~S}$ & Central Jakarta \\
\hline $35 \mathrm{kDa}$ & Cry30Aa 1 & $5 \mathrm{~K}$ & Cibinong, Bogor \\
\hline
\end{tabular}


biopesticide or as theuraphetic protein againts human cancer cells. The precise size of protein molecular weight of each strain is required to determine which study could be performed from which the data of the potencies of available proteins.

\section{REFERENCES}

Bel Y, Ganero F, Alberola TA, Martinez-Sebastian MJ, Ferré J. 1997. Distribution, frequency and diversity of Bacillus thuringiensis in olive tree environments. Spain Sys Appl Microbiol 20:652-8.

Bernhard K. 1986. Studies on the delta-endotoxin of Bacillus thuringiensis var. tenebrionis. FEMS Microbiol Lett 33:261-5.

Chaufaux J, Marchal M, Gilois N, Jehano I, Buison C. 1997. Research on natural strains of Bacillus thuringiensis in different biotopes throughout the world. Can J Microbiol 43:337-43.

Crickmore $\mathrm{N}$ et al. 2002. Bacillus turingiensis Toxin Nomenclature. The Bt delta-endotoxin nomenclature committee. 6 p.[on line] http://www.biols.susx.ac.uk/home/Neil_Crickmore/Bt/committee. html. Issued Mar 12, 2002. [Aug 27, 2002].

Laemmli UK. 1970. Cleavage of structural protein during the assembly of the head of bacteriophage T4. Nature 227:680-5.

Lee DW, Akao T, Yamashita S, Katayama H, Maeda M., Saitoh H., Mizuki E, Ohba M. 2000. Non-insecticidal parasporal proteins of a Bacillus thuringiensis serovar shandongiensis isolate exhibit a preferential cytotoxicity against human leukemic $\mathrm{T}$ cells. Biochem Biophys Res Comm 272:218-23.

Lee DW, Katayama H, Akao T, Maeda M, Tanaka R, Yamashita S, Saitoh H, Mizuki E. 2001. A $28 \mathrm{kDa}$ protein of the Bacillus thuringiensis serovar shandongiensis isolate 89-T-34-22 induces a human leukemic cell-specific cytotoxicity. Biochim Biophys Acta 1547:57-63.

Mizuki E, Ohba M, Akao T, Yamashita S, Saitoh H, Park YS. 1999. Unique activity associated with non-insecticidal Bacillus thuringiensis parasporal inclusions: in vitro cell-killing action on human cancer cells. J Appl Microbiol 86:979-84.

Ohba M, Mizuki E, Uemori A. 2009. Parasporin, a new anticancer protein group from Bacillus thuringiensis. Anticancer Res 29:42733.

Schnepf HE, Schwab GE, Payne JM, Enarva K, Foncerrada L. 1992. Patent WO92/19739.

Schnepf HE, Crickmore N, Rie JV, Lereclus D, Baum J, Feitelson J, Zeigler DR, Dean DH. 1998. Bacillus thuringiensis and its pesticidal crystal proteins. Microbiol Mol Biol Rev 62:775-806.

Travera MS, Martin PAW, Reicheldelfer CF. 1987. Selective process for efficient isolation of soil Bacillus sp. Appl Environ Microbiol 53:1263-6.

Xu Z, Yao B, Sun M, Yu Z. 2004. Protection of mice infected with Plasmodium berghei by Bacillus thuringiensis crystal proteins. Parasitol Res 92:53-7. 